\title{
Field, petrographic and geochemical characteristics of Sullya alkaline complex in the Cauvery Shear Zone (CSZ), southern India: Implications for petrogenesis
}

\author{
Chandan Kumar Boraiaha ${ }^{1, *}$, Kumar Batuk Joshi ${ }^{2}$, \\ Andrew C KerR ${ }^{3}$, Jayant Kumar Padhi ${ }^{1}$, \\ Sarbartha Shankar Mishra ${ }^{1}$ and Rashmi Chandan ${ }^{1}$ \\ ${ }^{1}$ Ore Research $\& 3$ Exploration (ORE) Group, Department of Geology, SESS, Central University of Kerala, \\ Kasaragod, Kerala 671 320, India. \\ ${ }^{2}$ National Centre for Earth Science Studies (NCESS), Akkulam, Trivandrum, Kerala 695 320, India. \\ ${ }^{3}$ School of Earth and Ocean Sciences, Cardiff University, Cardiff, Wales, UK. \\ ${ }^{*}$ Corresponding author.e-mail: rcgeo85@icloud.com
}

MS received 8 August 2019; revised 10 January 2020; accepted 19 January 2020

Significant, but volumetrically smaller, unmetamorphosed and largely undeformed alkaline magmatic suites have been reported from the Southern Granulite Terrain in southern India. These Neoproterozoic alkaline magmatic rocks occur as lenses, dykes and plugs that are mostly within, or proximal to, major shear zones or transcrustal faults. In this contribution, field, petrographic and whole-rock geochemical data of Sullya syenites and associated mafic granulites from the Mercara Shear Zone (MSZ), which separates low-grade (greenschist to upper amphibolite facies) Dharwar Craton and high-grade (granulite facies) Southern Granulite Terrain is presented. The isolated body of the Sullya syenite, similar to other alkaline plutons of the Southern Granulite Terrain, shows an intrusive relationship with the host hornblende-biotite gneisses and mafic granulites. The Sullya syenites lack macroscopic foliations and unlike, other plutons, they are not associated with carbonatites and ultrapotassic granites. Potash feldspar and plagioclase dominates the felsic phases in the Sullya syenite and there is negligible quartz. The studied syenites show evidence of melt supported deformation, but show no evidence of recrystallization. Geochemically, they most resemble the Angadimogar syenites (situated $3 \mathrm{~km}$ west of the Sullya syenites) with similar major oxide and trace element concentrations. The petrogenetic studies of the Sullya syenite have indicated that they were generated by mixing of two different sources derived from the partial melting of metasomatized continental mantle lithosphere and lower crustal mafic granulites. This melt source could have been emplaced in a rift-related tectonic setting. The emplacement is considered to be controlled by shears.

Keywords. Alkaline igneous rocks; syenites; Mercara shear zone, Coorg. 


\section{Introduction}

Alkaline igneous rocks are defined as those which have higher concentrations of alkali elements (mainly, $\mathrm{Na}$ and $\mathrm{K}$ ) than can be accommodated in feldspars with the excess alkalis forming feldspathoids, sodic pyroxenes, sodic amphiboles and other alkali-rich phases (Fitton and Upton 1987). Although, volumetrically these rocks account for less than one percent of all igneous rocks, their mineralogical diversity, petrogenetic history, tectonic significance and economic potential for resources of rare earth elements has long been of interest to geologists (Fitton and Upton 1987; Tchameni et al. 2001). The geochemistry of these rocks can provide information about their source characteristics, magma evolution and tectonic setting. In addition to this however, because of their rarity, they are also of fundamental importance to our understanding of the crustal and mantle evolution in both time and space and can help in formulating regional tectonomagmatic models (e.g., Menzies 1987; Ratnakar and
Leelanandam 1989; Müller et al. 1992; Bonin 2004; $\mathrm{Lu}$ et al. 2013).

The Southern Granulitic Terrain (SGT; figure 1) in India consists predominantly of Archean metamorphic suites that include charnockites, TTG (tonalite-trondhjemite-granodiorite) suite, amphibolites, mafic and ultramafic rocks, granitoids and metasedimentary sequences. Significant, but volumetrically smaller, unmetamorphosed and largely undeformed alkaline magmatic suites including syenites, ultrapotassic rocks, carbonatites, lamproites and shonkinites have also been reported from the SGT (Santosh et al. 2014). More than 20 alkaline complexes have been reported in the southern granulite terrain (SGT) of the Indian shield, all of them occurring in close proximity to or within the crustal scale shear zones (figure 1; Ratnakar and Leelanandam 1989). These alkaline magmatic rocks occur as lenses, dykes and plugs that are mostly within, or proximal to, major shear zones or transcrustal faults. These alkaline igneous suites are most common in the northern part of the SGT. The geochemistry and geochronology of some
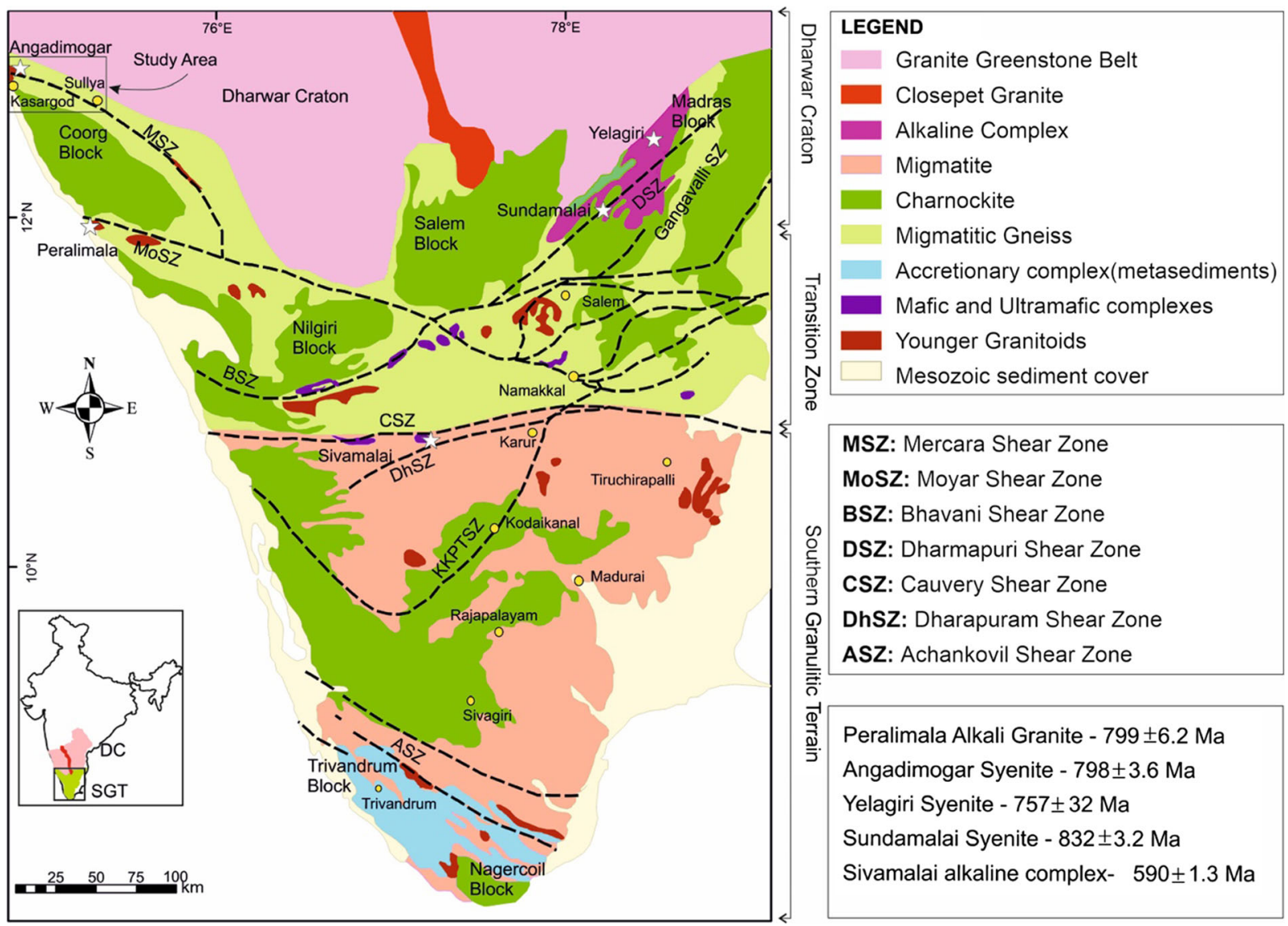

Figure 1. Geological map of Southern Granulite Terrain (SGT; after Chetty et al. 2012) (Isotopic dates are for individual plutons are from Santosh et al. (2014) (Peralimala and Angadimogar); Miyazaki et al. (2000) (Yelagiri); Renjith et al. (2016a) (Sundamalai); Upadhyay et al. (2006) (Sivamalai)). 
alkaline suites occurring within, or proximal to, the Dharmapuri Shear Zone (DSZ), the Mercara Shear Zone (MSZ) and the Moyar Shear Zone (MoSZ) have been studied previously (Mukhopadhyay et al. 2011; Santosh et al. 2014; Renjith et al. 2016a, b). However, little is known about the field and petrographic characters of the syenites of the MSZ and in this paper we will integrate new geochemical analyses with detailed field and petrographic data from a previously unstudied syenite along the MSZ. Our new data will be compared to, and integrated with, other syenites in the northern part of the SGT.

In this contribution, therefore we present field, petrographic and whole rock geochemical data of the Sullya syenites and associated mafic granulites from the Mercara Shear Zone (MSZ), which separates low-grade (greenschist to upper amphibolite facies) Dharwar Craton (DC) and high-grade (granulite facies) SGT in southern India. We will use our new data to help infer the petrogenesis of these alkaline complexes, nature of source rocks and their tectonic setting. Finally, we evaluate the different models that have been proposed to explain the genesis of these complexes.

\section{Geological framework}

The SGT (figure 1) consists of polymetamorphic crustal blocks (Nilgiri, Salem, Madurai, Trivandrum and Nagercoil) that were accreted at various times from the Mesoarchean to the Cambrian (Santosh et al. 2009; Collins et al. 2014). These crustal blocks are separated from the Dharwar Craton in the north by a complex set of ductile shear zones, which are collectively referred as Cauvery Shear Zone (CSZ; figure 1) (Chetty et al. 2003). The blocks to the south of the CSZ are commonly affected by the Late Neoproterozoic-Cambrian high grade metamorphism (Santosh et al. 2014). Two stages of tectonic movements in CSZ have been proposed by Chetty et al. (2003): (1) a Paleoproterozoic thrust (trending NW-SE) between the Nilgiri hills and Dharwar Craton in the north of CSZ, and (2) a set of several smaller shear zones in the south of CSZ resulting from Neoproterozoic transpressional tectonics. Alternatively, Ghosh et al. (2004) proposed that the Karur-Kambam-Painavu-Trissur shear zone (KKPTSZ), which trends NE-SW to the south of CSZ (figure 1), represented the boundary between Archean (Dharwar Craton) and Proterozoic (SGT) domains. More, recently, Rekha et al. (2014) summarized $\mathrm{U}-\mathrm{Pb}$ zircon ages and $\mathrm{U}-\mathrm{Th}$-total $\mathrm{Pb}$ ages in monazites from the gneisses, schists and granulites and proposed that the northern margin of the CSZ marks the zone of accretion of the western Dharwar Craton (WDC).

Several Neoproterozoic intrusive alkaline complexes have been reported from the SGT distributed along the fault/shear zones (figure 1) (Miyazaki et al. 2003; Upadhyay et al. 2006; Mukhopadhyay et al. 2011; Renjith et al. 2016a and references therein). Only a few of these alkaline complexes have been dated: Upadhyay et al. (2006) reported $590 \pm 1.3 \mathrm{Ma}$ U-Pb TIMS date of zircon from a pegmatite-syenite from Sivamalai alkaline complex, Dharapuram Shear Zone (DhSZ). Santosh et al. (2014) reported $798 \pm 3.6 \mathrm{Ma}$ and $799 \pm 6.2 \mathrm{Ma}$ U-Pb zircon ages from Angadimogar syenite (Mercara Shear Zone) and Peralimala alkali granite (Moyar Shear Zone), respectively. Renjith et al. (2016a) reported 832.6 $\pm 3.2 \mathrm{Ma}$ zircon $\mathrm{U}-\mathrm{Pb}$ ages from the Sundamalai syenites in Dharmapuri Shear Zone (DSZ). Schleicher et al. (1997, 1998) and Miyazaki et al. (2000), using various isotopic constraints, have dated carbonatite-pyroxenite-syenite association from Elagiri alkaline complex at $800 \mathrm{Ma}$.

\section{Field and petrographic characteristics of shear zone alkaline complexes north of CSZ - a comparison}

Detailed accounts of the field setting and mineralogy of many of the syenite plutons north of CSZ (except Sullya syenites) can be found in Upadhyay et al. (2006), Mukhopadhyay et al. (2011), Santosh et al. (2014), and Renjith et al. (2016a), and these are summarised in section 3.1. Detailed descriptions of the field relationships and petrography of the Sullya syenites, which are investigated in the present study, are given in section 3.2. An attempt is made here to summarize and compare the available diagnostic field and petrographic features of shear zone alkaline complexes north of CSZ.

\subsection{General characteristics of syenites north of the CSZ}

\subsubsection{Field characteristics}

Of the 11 alkaline complexes in the Dharampuri Shear Zone (DSZ, figure 1), the Sundamalai and Elagiri complexes have recently been studied in 
terms of their geochemistry (Mukhopadhyay et al. 2011; Renjith et al. 2016a). Detailed field and petrographic studies are however not available for these plutons. A common attribute of all the alkaline complexes found in the DSZ is that they intrude gneissic country rocks. However, these country rocks are lithologically variable and this has led to differences in interpreting the petrogenetic history of the alkaline complexes (for instance, Mukhopadhyay et al. 2011). The Elagiri alkaline complex consists of syenite, gabbro and hornblende gabbro that intrudes granite gneisses, amphibolites and pyroxene granulites and is cross cut by later lamprophyres and carbonatites. However, the Sundamalai syenites are characterised by the absence of carbonatite-ultramafic associations as well as K-feldspar megacrysts, though they show intrusive relationship with epidote-hornblende gneissic country rocks (Renjith et al. 2016a).

The Sivamalai alkaline complex (ferrosyenite-syenite-nepheline syenite) also shows an intrusive contact with the surrounding strongly deformed granite gneisses within the Dharapuram Shear Zone (DhSZ). The syenite pluton is found to be intruding mafic and ultramafic rocks (undefined) and charnockites (Upadhyay et al. 2006), and devoid of carbonatite units. Ferrosyenite unit seems to be intruding predominating syenites, while nepheline syenite unit post-dates the ferrosyenites and syenites (Upadhyay et al. 2006).

Little field information is available in the published literature about the Angadimogar syenite and the Peralimala alkali granite plutons in the Mercara Shear Zone (MSZ) and Moyar Shear Zone (MoSZ), respectively. However, the Angadimogar pluton is reported to intrude high-grade felsic gneisses while the Peralimala granite intrudes hornblende- and biotite-bearing tonalite-trondhjemite-granodiorite (TTG) gneisses (Ratnakar and Leelanandam 1989; Santosh et al. 2014). The angle of intrusion and depth related information on the plutons, which is crucial in deciphering their genesis, is missing for almost all the alkaline complexes reported so far in the north of CSZ. Mafic magmatic enclaves (MMEs) of various dimensions are reported from Angadimogar syenites while these are not present in the Peralimala granites. The enclaves are partially resorbed and show sharp contacts with the host syenites. The preferred orientation of the long axis with a crude magmatic foliation in the enclaves is also reported from the Angadimogar syenites (Santosh et al. 2014).
No carbonatite-ultramafic lithological units are reported from these two areas.

\subsubsection{Petrographic characteristics}

With the exception of modal mineralogy and grain size, little information is reported on the petrographic characteristics of the syenite plutons north of CSZ (except for the Sivamalai syenites).

Perthitic alkali feldspar and subordinate nepheline are the major felsic phases reported from the Sivamalai syenites (Subramaniam 1948; Bose 1971; Rao 1982; Upadhyay et al. 2006). Ferromagnesian minerals include opaque phases (ilmenite and magnetite), biotite and occasional greenish amphibole. Apatite, zircon, rutile and plagioclase are the main accessory phases. Based on textural and grain boundary relations, Upadhyay et al. (2006) have reported a granoblastic texture, ductile deformation and recrystallization at fairly high temperatures from these syenites. Layering in the Sivamalai syenites is also reported based on the compositional banding of fine grained mafic layers and coarse grained alkali feldspar rich layers.

The syenites of the Elagiri complex has been grouped into four types based on its mineralogy and modal proportion: leuco, pink, grey and porphyritic. In this complex, the felsic phases comprise alkali feldspar and plagioclase with minor quartz, while pyroxene and amphibole form the mafic phases. Dominant felsic phases reported from the Angadimogar syenites are alkali feldspar, plagioclase and quartz while mafic phases comprise ferroedenite (phenocrysts and groundmass) and biotite (Santosh et al. 2014). A hypidiomorphic inequigranular texture with plagioclase (20-60\%), amphibole (10-25\%), K-feldspar (5-20\%) and quartz $(5-10 \%)$ as essential minerals and $\mathrm{Fe}-\mathrm{Ti}$ oxide, zircon, titanite, biotite and apatite as minor/accessory phases are reported from the syenites of Sundamalai (Renjith et al. 2016a).

\subsection{Sullya syenite}

\subsubsection{Field characteristics}

This study in the Mercara Shear Zone (MSZ), $3 \mathrm{~km}$ east of the Angadimogar pluton (referred as to as the Permuda syenites) and in Sullya town ( $~ 50 \mathrm{~km}$ southwest of the Angadimogar pluton; referred as the Sullya syenites), revealed the association of syenites with mafic-granulites and 


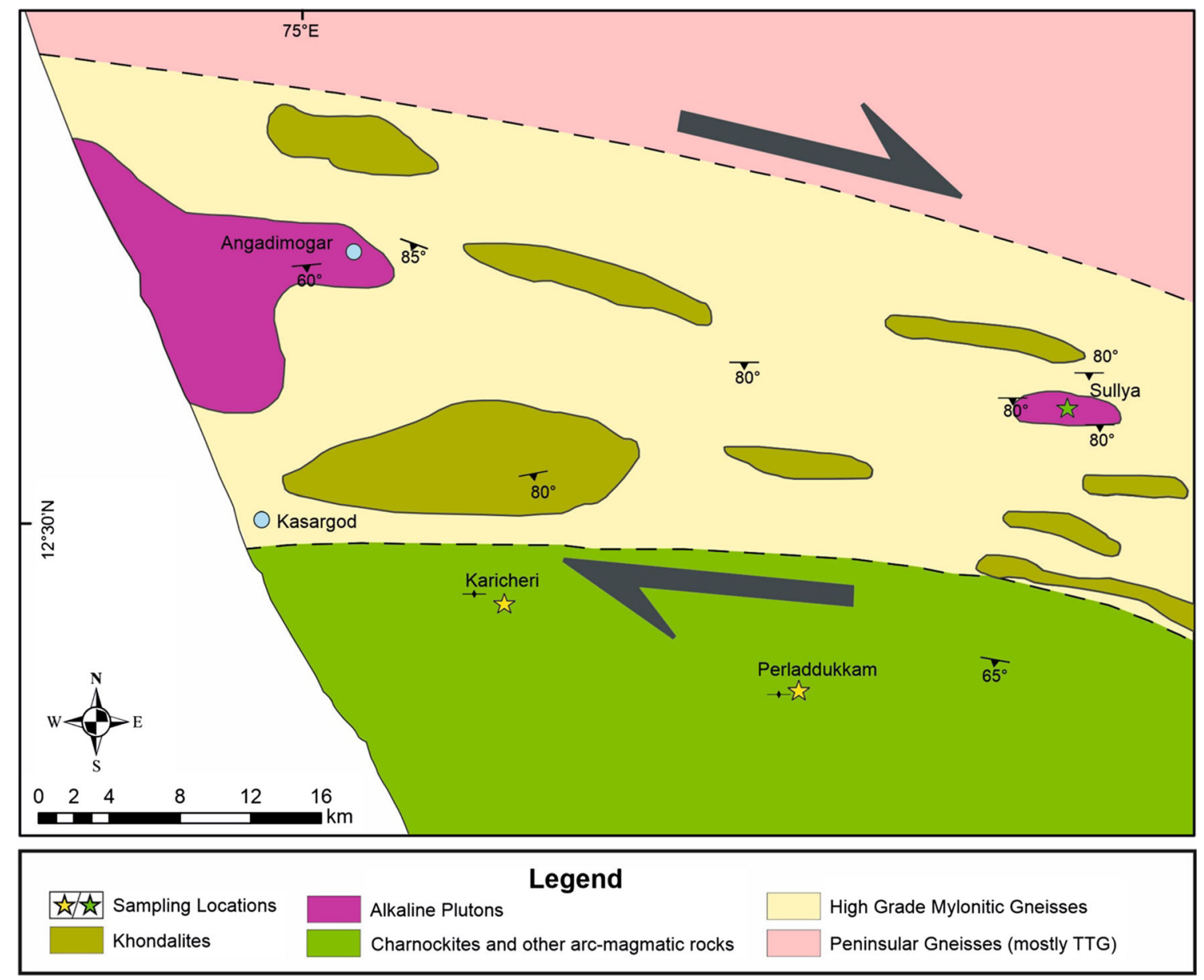

Figure 2. Geological map of the study area (after Chetty et al. 2012).

hornblende-biotite gneisses (figures 2 and 3). The Permuda syenite has an intrusive contact with the granulites while its boundary relationship with gneisses is largely undetermined due to lack of exposures. However, since the mafic-granulites are high-grade metamorphic products of basement gneisses, it can be inferred that the syenites have also intruded into the gneisses. Two sets of joints, $\sim 12-15 \mathrm{~cm}$ wide and trending WNW and NE-SW with sub-vertical dips, are impregnated with secondary basaltic material (fine grained material mainly composed of mafic minerals).

The Sullya syenite pluton (figures 2 and 3) in Dakshina Kannada district of Karnataka was first reported by Ravindra and Janardhan (1981). Detailed field investigations as part of this study have shown that the contact between syenite and surrounding hornblende-biotite gneiss are rarely exposed, but wherever they are exposed, the syenite shows an intrusive relationship with an EW striking contact having $68^{\circ}$ southerly dip. The syenites rarely show any foliation and are characterized by decreasing grain size from its centre towards the contact with gneisses, indicating their intrusive nature. Potassic alteration resulting in the enrichment of K-feldspar and biotite in the gneissic wall rocks has been observed and this alteration zone probably extends up to a maximum of $1 \mathrm{~m}$ into the country rocks. Sulphide specks are discernible both in the intrusive syenites and wall rocks; however, no significant mineralization could be located in the surface exposures. The syenites are highly jointed with two sets of joints cross trending WNW and NE-SW approximately perpendicular to each other, with sub-vertical dips, similar to the Angadimogar (Permuda) syenites. More widespread joints $(\sim 5 \mathrm{~cm})$ are filled with very finegrained secondary basaltic material.

The syenites of Sullya are mostly homogeneous and are medium to coarse grained with the crystal size gradually increasing from the rim to core of the pluton where the grains are $>3 \mathrm{~cm}$ and the rocks resemble pegmatites. At places within the main body of the pluton, rock is distinctly porphyritic 

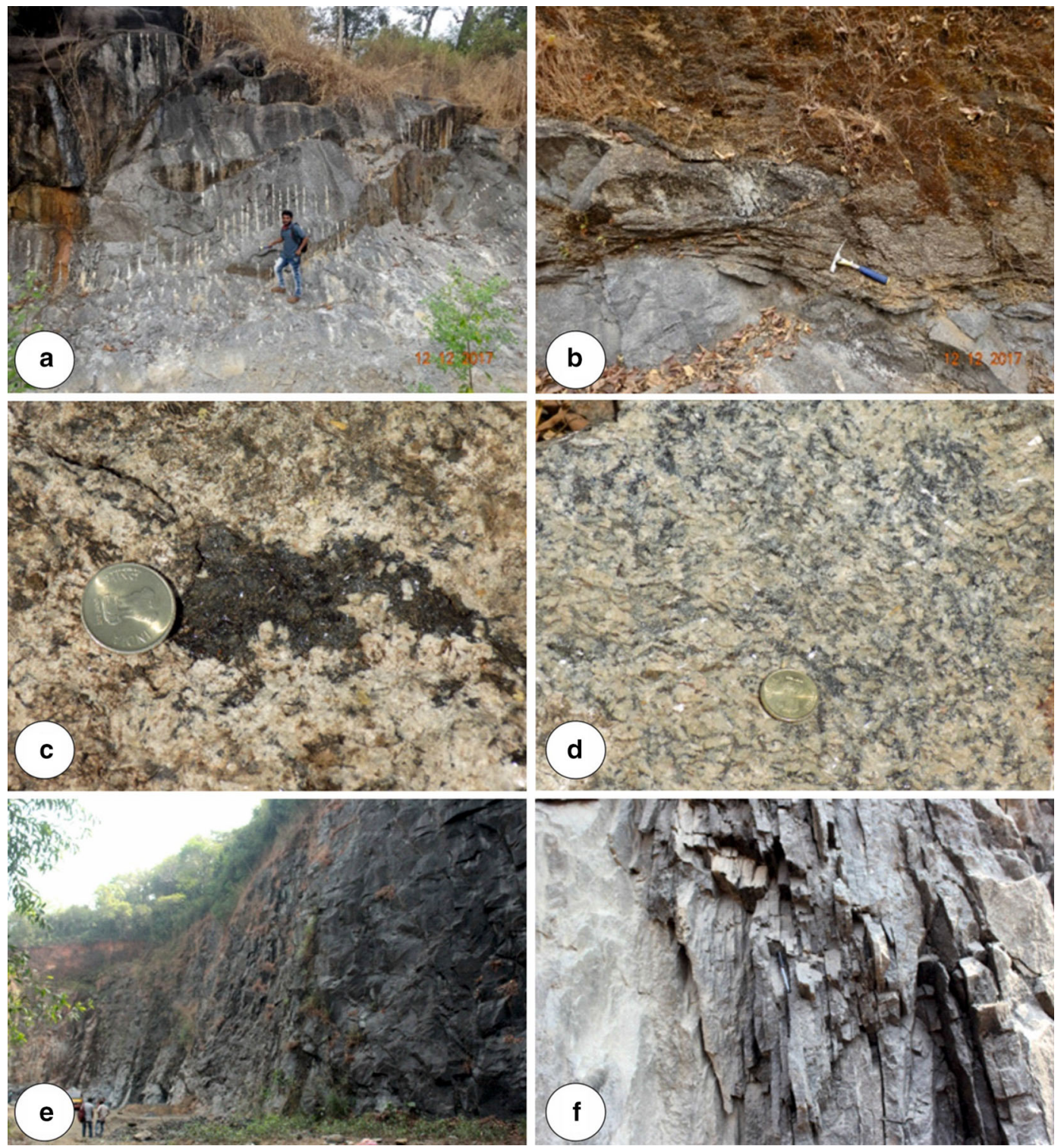

Figure 3. Field photographs of Sullya syenite $(\mathbf{a}-\mathbf{d})$ and associated mafic granulites $(\mathbf{e}, \mathbf{f})$. The diameter of the coin is $\sim 2 \mathrm{~cm}$.

and exhibit well developed laths of feldspars within mafic groundmass. The mafic clots are mainly composed of aegirine-augite that is locked-in K-feldspar grains (figure 3). Quartz is negligible and the pluton is devoid of feldspathoids. The longer axis of feldspar phenocrysts and mafic clots within Sullya syenite show a very weak alignment (figure 4) resulted due to melt supported deformation. Clear evidences of solid state ductile shearing are conspicuous in both mafic clots and feldspars (figure 4).

\subsubsection{Petrography}

They contain predominantly K-feldspars (perthite; $\sim 55 \%)$ and plagioclase $(\sim 32 \%)$ with $<5 \%$ modal quartz. Ferromagnesian phases $(\sim 16 \%)$ are represented by aegirine, ribeckite (arfvedsonite), opaque oxides and occasional hornblende \pm biotite (figure 4). Similar ferromagnesian phases are reported in Sullya syenites by Ravindra and Janardhan (1981). Zircon and apatite are accessory phases occurring as inclusions within the feldspars. The rock exhibits a holocrystalline intergranular texture and non-directional fabric with crystal shapes varying from euhedral to subhedral. Medium to fine grained quartz and albite together in the form of vein are seen cross cutting coarser K-feldspar and plagioclase grains. Occasionally these vein-like features are seen occupying interstitial spaces between coarsegrained feldspars. Pyroxenes and amphiboles 

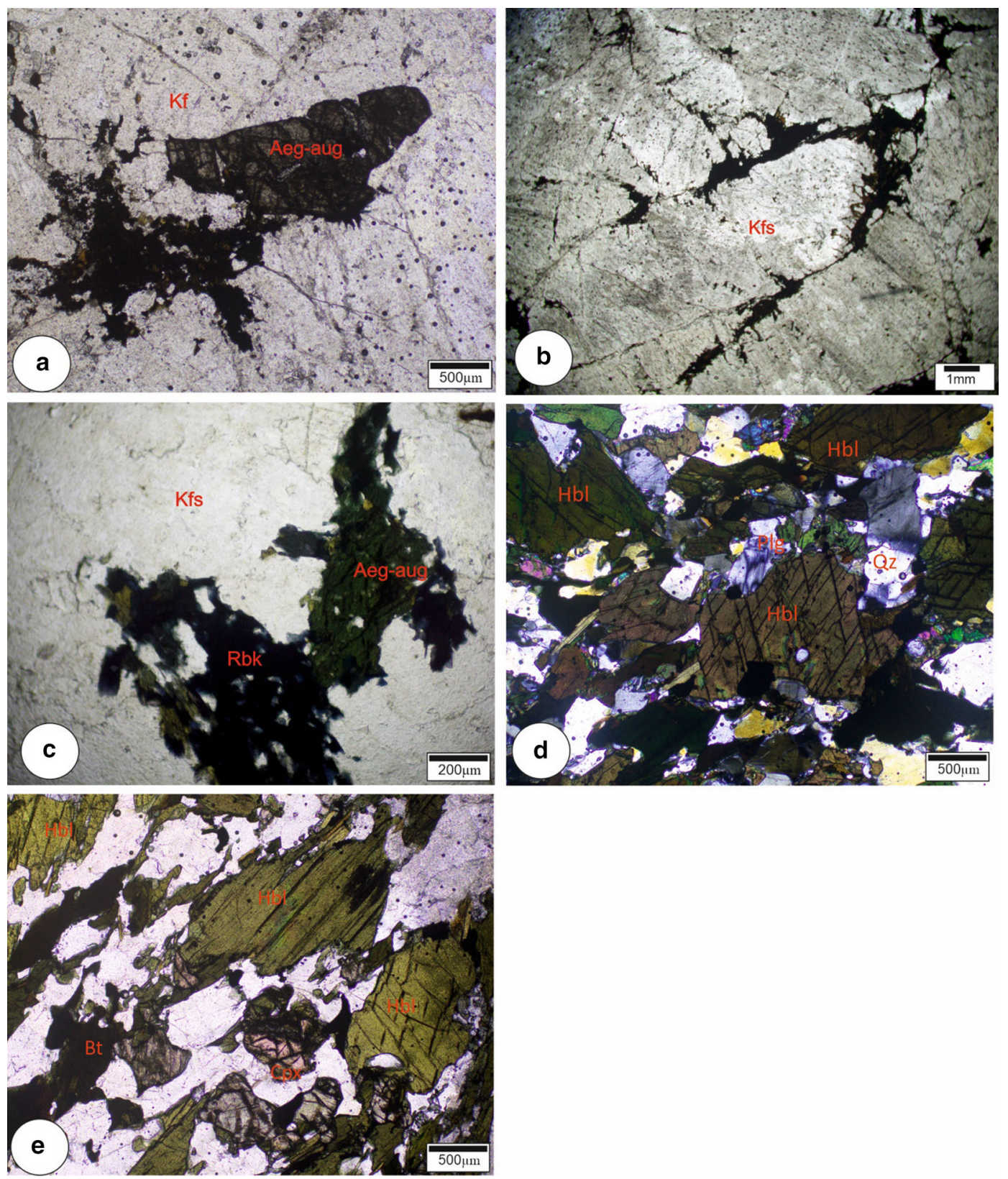

Figure 4. Photomicrographs of Sullya syenite (a-c) and associated mafic granulites (d, e) (Kf: potash felspar; Ag: aegirine; Rb: riebeckite; Hbd: hornblende; Bt: biotite; Plg: plagioclase; Cpx: clinopyroxene).

occur as clots and are seen mantling K-feldspar megacrysts resulting in the rounded edges of K-feldspar laths due to partial dissolution. The pyroxene/amphibole mantle is seen as a cluster of aegirine/riebeckite (arfvedsonite) crystals included around the rim of the quartz. At grain boundaries, where the partial dissolution of K-feldspar has taken place, the K-feldspar grains are seen locked-in the adjacent aegirine/ribeckite (arfvedsonite) crystals indicating that K-feldspar was an earlier crystallising phase after which came pyroxene/amphiboles. No evidence of secondary recrystallization has been found as in Sivamali syenites.

Mafic granulites, into which the studied syenites intrude, contains hornblende $(\sim 53 \%)$, plagioclase $(\sim 20 \%)$ and quartz $(13 \%)$ as major minerals and pyroxene $(\sim 9 \%)$ and biotite $(\sim 5 \%)$ as minor minerals (figure 4$)$. Opaque oxides form the accessory phase. The rocks are medium to coarse-grained, exhibit granoblastic texture and occasionally display weak foliation manifested by the parallel orientation of directional minerals such as hornblende, biotite and 
Table 1. Whole rock geochemical analyses of Sullya syenites and associated mafic granulites (major oxides in wt\% and trace elements in ppm)

\begin{tabular}{|c|c|c|c|c|c|c|c|c|c|c|}
\hline \multirow{2}{*}{$\begin{array}{l}\text { Sl. no } \\
\text { Rocktype }\end{array}$} & SS-1 & SS-2 & SS-3 & $\mathrm{SS}-4$ & SS-5 & SS-6 & SS-7 & SS-8 & SS-9 & SS-10 \\
\hline & \multicolumn{10}{|c|}{ Sullya syenite } \\
\hline $\mathrm{SiO}_{2}$ & 63.6 & 63.8 & 63.7 & 63.8 & 63.9 & 63.9 & 63.9 & 63.8 & 64.4 & 64.8 \\
\hline $\mathrm{TiO}_{2}$ & 0.2 & 0.3 & 0.2 & 0.2 & 0.1 & 0.2 & 0.2 & 0.2 & 0.1 & 0.1 \\
\hline $\mathrm{Al}_{2} \mathrm{O}_{3}$ & 16.8 & 16.7 & 16.8 & 16.7 & 17.5 & 16.5 & 17.2 & 16.2 & 17.6 & 17.9 \\
\hline $\mathrm{Fe}_{2} \mathrm{O}_{3}$ & 5.1 & 5.1 & 5.1 & 5.1 & 4.2 & 5.4 & 4.6 & 5.7 & 3.7 & 3.4 \\
\hline $\mathrm{MnO}$ & 0.18 & 0.18 & 0.18 & 0.18 & 0.18 & 0.18 & 0.18 & 0.18 & 0.13 & 0.11 \\
\hline $\mathrm{MgO}$ & 0.03 & 0.05 & 0.04 & 0.04 & 0.04 & 0.04 & 0.04 & 0.04 & 0.04 & 0.07 \\
\hline $\mathrm{CaO}$ & 2.0 & 2.0 & 2.0 & 2.0 & 2.0 & 2.2 & 2.1 & 2.2 & 1.6 & 1.4 \\
\hline $\mathrm{Na}_{2} \mathrm{O}$ & 5.8 & 5.6 & 5.7 & 5.6 & 5.8 & 5.6 & 5.7 & 5.5 & 5.8 & 5.9 \\
\hline $\mathrm{K}_{2} \mathrm{O}$ & 6.1 & 6.1 & 6.1 & 6.1 & 6.2 & 5.9 & 6.1 & 5.8 & 6.5 & 6.1 \\
\hline $\mathrm{P}_{2} \mathrm{O}_{5}$ & 0.04 & 0.06 & 0.05 & 0.05 & 0.04 & 0.08 & 0.05 & 0.09 & 0.05 & 0.06 \\
\hline $\mathrm{Co}$ & 0.47 & 0.53 & 0.50 & 0.51 & 0.37 & 0.54 & 0.42 & 0.59 & 0.40 & 0.48 \\
\hline $\mathrm{Ni}$ & 5.6 & 3.0 & 4.3 & 3.7 & 2.8 & 2.5 & 2.7 & 2.5 & 5.6 & 4.4 \\
\hline $\mathrm{Rb}$ & 59 & 63 & 61 & 62 & 52 & 61 & 55 & 64 & 54 & 56 \\
\hline $\mathrm{Sr}$ & 55 & 60 & 57 & 58 & 49 & 37 & 45 & 33 & 74 & 133 \\
\hline Cs & 0.77 & 0.99 & 0.88 & 0.93 & 0.89 & 1.32 & 1.03 & 1.47 & 0.43 & 0.40 \\
\hline $\mathrm{Ti}$ & 1128 & 1512 & 1320 & 1416 & 882 & 1125 & 963 & 1206 & 864 & 890 \\
\hline $\mathrm{V}$ & 0.44 & 0.57 & 0.51 & 0.54 & 0.02 & 0.17 & 0.07 & 0.22 & 0.16 & 0.81 \\
\hline $\mathrm{Ta}$ & 0.73 & 0.89 & 0.81 & 0.85 & 0.87 & 0.78 & 0.84 & 0.75 & 0.70 & 0.59 \\
\hline $\mathrm{Nb}$ & 14 & 15 & 15 & 15 & 21 & 15 & 19 & 13 & 16 & 14 \\
\hline $\mathrm{Zr}$ & 63 & 27 & 45 & 36 & 71 & 54 & 65 & 48 & 36 & 91 \\
\hline $\mathrm{Hf}$ & 1.58 & 0.94 & 1.26 & 1.10 & 1.46 & 1.36 & 1.42 & 1.33 & 1.01 & 2.07 \\
\hline $\mathrm{Y}$ & 10 & 8 & 9 & 9 & 9 & 10 & 9 & 11 & 10 & 10 \\
\hline $\mathrm{La}$ & 57.14 & 58.34 & 57.74 & 58.04 & 27.20 & 17.87 & 24.09 & 14.76 & 153.07 & 148.11 \\
\hline $\mathrm{Ce}$ & 123.96 & 127.71 & 125.84 & 126.77 & 66.87 & 53.39 & 62.38 & 48.90 & 300.24 & 289.64 \\
\hline $\operatorname{Pr}$ & 17.15 & 18.05 & 17.60 & 17.82 & 10.10 & 9.76 & 9.98 & 9.64 & 39.23 & 36.32 \\
\hline $\mathrm{Nd}$ & 62.68 & 66.28 & 64.48 & 65.38 & 42.00 & 44.33 & 42.78 & 45.11 & 139.34 & 126.28 \\
\hline $\mathrm{Sm}$ & 9.81 & 9.64 & 9.72 & 9.68 & 7.54 & 8.83 & 7.97 & 9.26 & 16.20 & 14.61 \\
\hline $\mathrm{Eu}$ & 2.70 & 2.57 & 2.63 & 2.60 & 2.52 & 2.05 & 2.37 & 1.89 & 3.84 & 3.41 \\
\hline $\mathrm{Gd}$ & 16.27 & 18.56 & 17.42 & 17.99 & 11.24 & 11.51 & 11.33 & 11.59 & 41.21 & 34.60 \\
\hline $\mathrm{Tb}$ & 1.21 & 1.26 & 1.23 & 1.25 & 1.02 & 1.13 & 1.06 & 1.17 & 2.16 & 1.85 \\
\hline Dy & 3.73 & 3.61 & 3.67 & 3.64 & 3.58 & 4.00 & 3.72 & 4.14 & 4.37 & 3.91 \\
\hline Ho & 0.66 & 0.60 & 0.63 & 0.61 & 0.58 & 0.68 & 0.61 & 0.71 & 0.68 & 0.62 \\
\hline Er & 2.54 & 2.32 & 2.43 & 2.37 & 1.97 & 2.25 & 2.07 & 2.35 & 3.27 & 2.85 \\
\hline $\mathrm{Tm}$ & 0.26 & 0.21 & 0.24 & 0.22 & 0.20 & 0.24 & 0.22 & 0.26 & 0.23 & 0.21 \\
\hline $\mathrm{Yb}$ & 2.06 & 1.75 & 1.90 & 1.83 & 1.60 & 1.90 & 1.70 & 2.00 & 1.87 & 1.68 \\
\hline $\mathrm{Lu}$ & 0.33 & 0.28 & 0.31 & 0.30 & 0.26 & 0.31 & 0.28 & 0.32 & 0.27 & 0.25 \\
\hline $\mathrm{Cu}$ & 4.00 & 5.95 & 4.98 & 5.46 & 2.68 & 7.82 & 4.40 & 9.54 & 1.73 & 1.87 \\
\hline $\mathrm{Zn}$ & 133 & 98 & 116 & 107 & 88 & 78 & 85 & 75 & 139 & 108 \\
\hline $\mathrm{Ga}$ & 21 & 21 & 21 & 21 & 21 & 21 & 21 & 21 & 24 & 23 \\
\hline Sl. no & & & SG-2 & SG-3 & & SG-4 & SG-5 & & SG-6 & SG-7 \\
\hline Rocktype & & & & & $\mathrm{Ma}$ & c-granulite & & & & \\
\hline $\mathrm{SiO}_{2}$ & & & 54.0 & 55.4 & & 61.6 & 57.9 & & 55.5 & 56.7 \\
\hline $\mathrm{TiO}_{2}$ & & & 2.1 & 1.2 & & 0.8 & 1.1 & & 1.6 & 1.3 \\
\hline $\mathrm{Al}_{2} \mathrm{O}_{3}$ & & & 9.9 & 13.4 & & 16.0 & 16.0 & & 16.8 & 16.4 \\
\hline $\mathrm{Fe}_{2} \mathrm{O}_{3}$ & & & 10.0 & 9.4 & & 7.5 & 7.1 & & 7.4 & 7.2 \\
\hline $\mathrm{MnO}$ & & & 0.34 & 0.21 & & 0.23 & 0.13 & & 0.13 & 0.13 \\
\hline $\mathrm{MgO}$ & & & 9.3 & 6.8 & & 3.2 & 4.6 & & 3.4 & 4.0 \\
\hline $\mathrm{CaO}$ & & & 11.2 & 9.2 & & 5.0 & 7.4 & & 9.1 & 8.2 \\
\hline $\mathrm{Na}_{2} \mathrm{O}$ & & & 1.8 & 3.2 & & 4.6 & 4.3 & & 4.3 & 4.3 \\
\hline
\end{tabular}


Table 1. (Continued.)

\begin{tabular}{|c|c|c|c|c|c|c|c|}
\hline $\begin{array}{l}\text { Sl. no } \\
\text { Rocktype }\end{array}$ & SG-1 & SG-2 & SG-3 & $\begin{array}{c}\text { SG-4 } \\
\text { Mafic-granulite }\end{array}$ & SG-5 & SG-6 & SG-7 \\
\hline $\mathrm{K}_{2} \mathrm{O}$ & 0.97 & 1.07 & 0.84 & 0.67 & 1.02 & 0.77 & 0.89 \\
\hline $\mathrm{P}_{2} \mathrm{O}_{5}$ & 0.29 & 0.26 & 0.28 & 0.33 & 0.37 & 0.97 & 0.67 \\
\hline Co & 46 & 96 & 54 & 27 & 33 & 42 & 38 \\
\hline $\mathrm{Ni}$ & 62 & 154 & 135 & 94 & 97 & 95 & 96 \\
\hline $\mathrm{Rb}$ & 3 & 5 & 3 & 3 & 6 & 3 & 4 \\
\hline $\mathrm{Sr}$ & 322 & 89 & 204 & 364 & 352 & 598 & 475 \\
\hline Cs & 0.02 & 0.02 & 0.02 & 0.02 & 0.02 & 0.02 & 0.02 \\
\hline $\mathrm{Ti}$ & 7860 & 12300 & 7020 & 4986 & 6342 & 9720 & 8031 \\
\hline $\mathrm{V}$ & 293 & 421 & 231 & 188 & 225 & 324 & 275 \\
\hline $\mathrm{Ta}$ & 0.85 & 0.72 & 0.38 & 0.54 & 0.45 & 0.71 & 0.58 \\
\hline $\mathrm{Nb}$ & 19 & 15 & 8 & 11 & 11 & 19 & 15 \\
\hline $\mathrm{Zr}$ & 74 & 36 & 43 & 130 & 94 & 66 & 80 \\
\hline $\mathrm{Hf}$ & 1.82 & 1.35 & 1.17 & 2.42 & 1.88 & 1.43 & 1.65 \\
\hline $\mathrm{Y}$ & 51 & 48 & 27 & 19 & 35 & 47 & 41 \\
\hline $\mathrm{La}$ & 18.98 & 15.4 & 13.09 & 31.96 & 39.2 & 65.82 & 52.51 \\
\hline $\mathrm{Ce}$ & 51.05 & 47.93 & 33.54 & 65.49 & 95.41 & 156.98 & 126.19 \\
\hline $\operatorname{Pr}$ & 7 & 6.6 & 4.49 & 7.66 & 11.81 & 21.74 & 16.78 \\
\hline $\mathrm{Nd}$ & 30.83 & 29.26 & 19.19 & 30.02 & 49.76 & 86.69 & 68.23 \\
\hline $\mathrm{Sm}$ & 7.87 & 7.31 & 4.74 & 5.54 & 9.66 & 16.19 & 12.92 \\
\hline $\mathrm{Eu}$ & 1.98 & 1.8 & 1.44 & 1.92 & 2.51 & 3.59 & 3.05 \\
\hline $\mathrm{Gd}$ & 9.11 & 7.99 & 5.3 & 6.27 & 10.25 & 16.31 & 13.28 \\
\hline $\mathrm{Tb}$ & 1.61 & 1.44 & 0.91 & 0.82 & 1.45 & 2.18 & 1.81 \\
\hline Dy & 9.99 & 9.09 & 5.54 & 4.31 & 7.78 & 10.75 & 9.26 \\
\hline Но & 2.11 & 1.91 & 1.14 & 0.85 & 1.55 & 2.05 & 1.8 \\
\hline Er & 6.47 & 5.93 & 3.48 & 2.58 & 4.54 & 5.99 & 5.26 \\
\hline $\mathrm{Tm}$ & 0.98 & 0.89 & 0.52 & 0.37 & 0.63 & 0.79 & 0.71 \\
\hline $\mathrm{Yb}$ & 6.5 & 6.1 & 3.4 & 2.46 & 4.11 & 5.13 & 4.62 \\
\hline $\mathrm{Lu}$ & 1 & 0.9 & 0.5 & 0.39 & 0.61 & 0.74 & 0.68 \\
\hline $\mathrm{Cu}$ & 166 & 913 & 128 & 100 & 15 & 179 & 97 \\
\hline $\mathrm{Zn}$ & 83 & 140 & 88 & 240 & 121 & 88 & 105 \\
\hline $\mathrm{Ga}$ & 24 & 19 & 16 & 19 & 20 & 23 & 21 \\
\hline
\end{tabular}

plagioclase. Inclusions of quartz within hornblende is not uncommon.

\section{Geochemistry}

\subsection{Results}

The Sullya syenite is intermediate in composition with a narrow range of $\mathrm{SiO}_{2}$ (63.6-64.4 wt.\%; table 1). Alkali contents of these syenites are high (>10 wt.\%) and they plot in the fields of alkaline rocks on a total-alkali silica (TAS) diagram (figure 5a) and into the shoshonitic fields on the $\mathrm{K}_{2} \mathrm{O}$ vs. $\mathrm{SiO}_{2}$ diagram (figure $5 \mathrm{~b}$ ). The $\mathrm{MgO}$ content is markedly low (0.03-0.05 wt.\%) and the rocks are metaluminous with molar $(\mathrm{Na}+\mathrm{K}) /$
$\mathrm{Al}<1$ and molar $(\mathrm{Ca}+\mathrm{Na}+\mathrm{K}) / \mathrm{Al}<1$. These features indicate that the Sullya syenite is not likely to represent mantle-derived primary magma composition.

On an average, Sullya syenite have higher $\mathrm{SiO}_{2}$ and $\mathrm{Fe}_{2} \mathrm{O}_{3}$ contents than Sivamalai and Elagiri syenites, but lower than Sundamalai syenites (figure 6a). The $\mathrm{Al}_{2} \mathrm{O}_{3}$ in Sullya syenite is lower than Sivamalai but higher than Sundamalai. Lower silica and higher alumina content in Sullya syenite than Sundamalai syenites is due to low quartz and high feldspar mineralogy in the former. The average $\mathrm{SiO}_{2}, \mathrm{Fe}_{2} \mathrm{O}_{3}$ and $\mathrm{Al}_{2} \mathrm{O}_{3}$ of Angadimogar syenites almost matches with that of the Sullya syenite. The average $\mathrm{MgO}$ and $\mathrm{CaO}$ contents of Sullya syenite are significantly less than that of Elagiri and Sundamalai. This is likely due to 

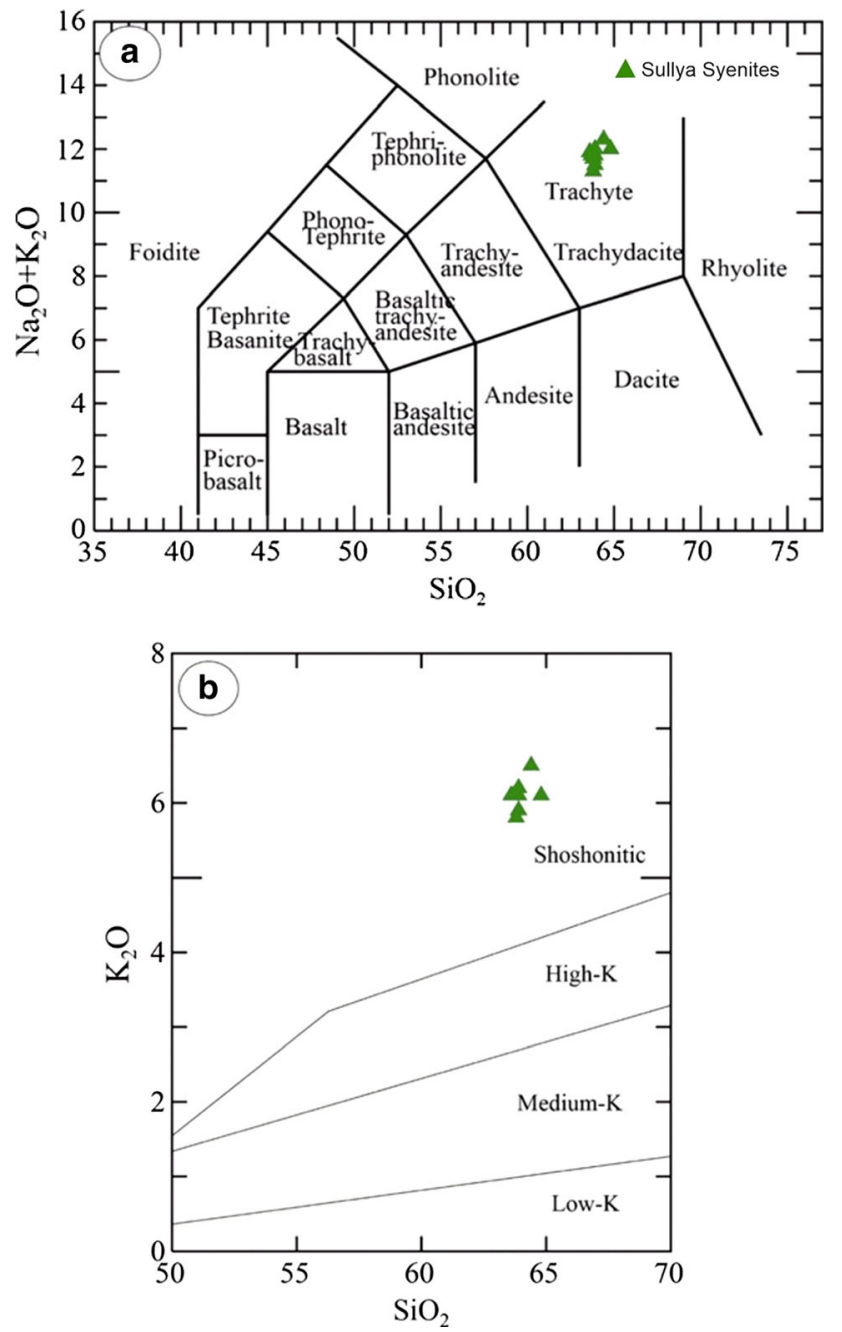

Figure 5. (a) Total alkali silica classification diagram for Sullya syenite (after Le Bas et al. 1986) and (b) $\mathrm{SiO}_{2}$ vs. $\mathrm{K}_{2} \mathrm{O}$ plot of Sullya syenite (after Peccerillo and Taylor 1976).

comparatively lower mafic phases in the Sullya syenite than Elagiri and Sundamalai syenites. Interestingly, the average $\mathrm{MgO}$ content of Sullya syenite is extremely low compared to that of the Angadimogar syenites. The total average alkali $\left(\mathrm{Na}_{2} \mathrm{O}+\mathrm{K}_{2} \mathrm{O}\right)$ content is higher in Sullya syenite than Angadimogar, Elagiri and Sundamalai syenites but lower than Sivamalai syenites, which is corroborated with the higher feldspar and feldspathoid and lower quartz content in Sivamalai syenites than the Sullya syenite (figure 6a).

Based on total rare earth element (REE; figure $6 \mathrm{~b}$ ) concentrations, the Sullya syenites are grouped into three types. Type- 1 syenites are characterized by moderate REE contents ranging between 301 and $311 \mathrm{ppm}$. They display light REE $(\mathrm{LREE})$ fractionation $\left[(\mathrm{La} / \mathrm{Sm})_{\mathrm{N}}=3.8-3.9\right]$ with negative europium anomalies $\left(\mathrm{Eu} / \mathrm{Eu}^{*}=0.58-\right.$ 0.65) and heavy REE (HREE) depletion $[(\mathrm{Gd} /$
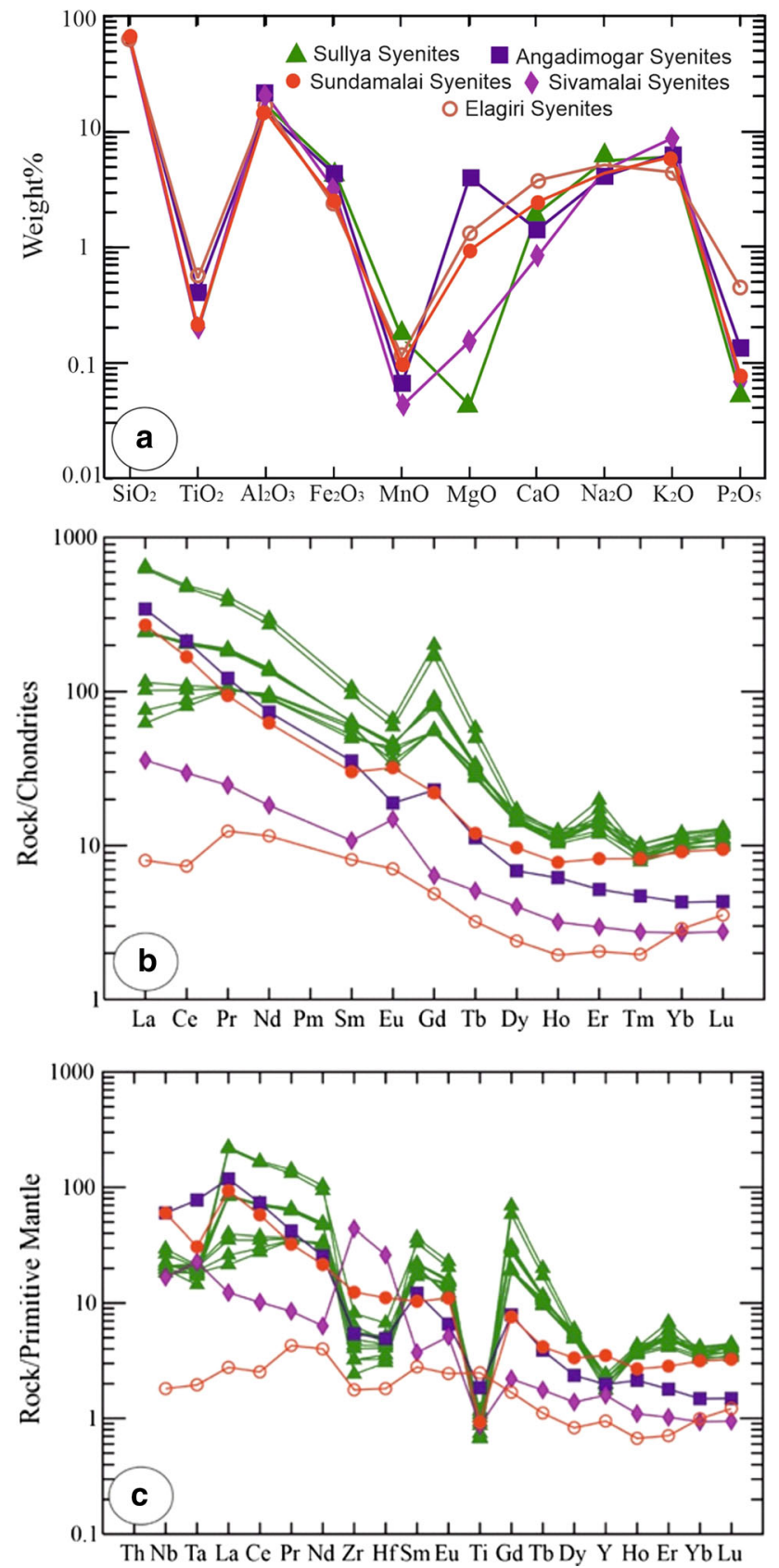

Figure 6. (a) Average major oxide variation plot for the syenite plutons in the north of CSZ (Data source: Sullya: this study; Angadimogar: Santosh et al. (2014); Sivamalai: Upadhyay et al. (2006); Elagiri: Mukhopadhyay et al. (2011); Sundamalai: Renjith et al. (2016a)); (b) Chondrite normalized rare earth element (REE) plot of syenites (Sun and McDonough 1989); and (c) Primitive mantle normalized multi-element plot of syenites (Sun and McDonough 1989).

$\left.\mathrm{Yb})_{\mathrm{N}}=6.5-8.8\right]$. Type-2 syenites are characterized by low REE contents ranging between 152 and 177 ppm. Relatively, they display low LREE fractionation $\left[(\mathrm{La} / \mathrm{Sm})_{\mathrm{N}}=1.0-2.3\right]$ with negative europium anomalies $\left(\mathrm{Eu} / \mathrm{Eu}^{*}=0.56-0.84\right)$ and heavy REE (HREE) depletion $\left[(\mathrm{Gd} / \mathrm{Yb})_{\mathrm{N}}=4.8-5.8\right]$. Type-3 syenites are characterized by high REE 

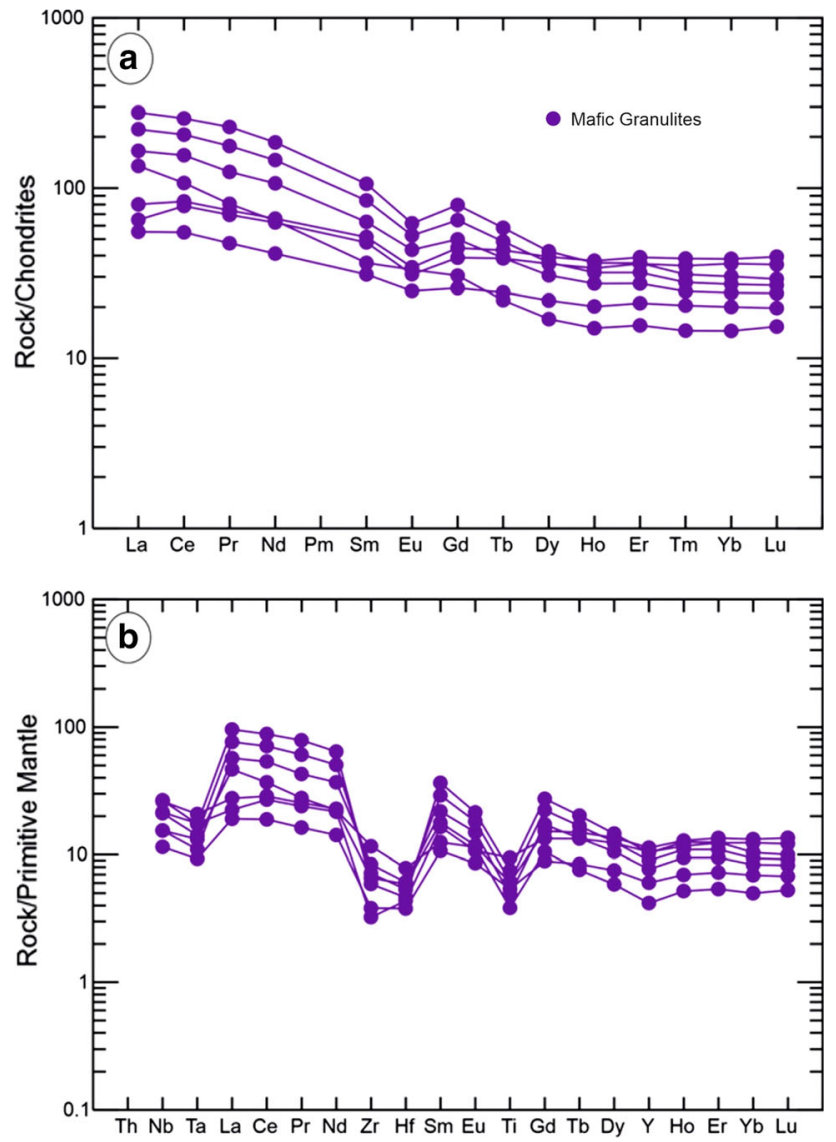

Figure 7. (a) Chondrite normalized rare earth element (REE) plot of mafic granulites (Sun and McDonough 1989) and (b) Primitive mantle normalized multi-element plot of mafic granulites (Sun and McDonough 1989).

contents ranging between 664 and $706 \mathrm{ppm}$. They display relatively high LREE enrichment $\left[(\mathrm{La} / \mathrm{Sm})_{\mathrm{N}}=6.1-6.5\right]$ with pronounced negative europium anomalies $\left(\mathrm{Eu} / \mathrm{Eu}^{*}=0.43-0.45\right)$ and marked heavy REE (HREE) depletion $[(\mathrm{Gd} /$ $\left.\mathrm{Yb})_{\mathrm{N}}=17.0-18.3\right]$.

The compatible and transitional element contents of the Sullya syenite are lower than the Angadimogar, Sivamalai, Elagiri and Sundamalai syenites. However, the incompatible trace elements in Sullya syenite are enriched than Elagiri syenites and are depleted than Angadimogar, Sivamalai and Sundamalai syenites (figure 6c). In comparison with REE of Sullya syenite, the Angadimogar, Sivamalai and Sundamalai syenites show highly fractionated LREE. The HREE is more highly fractionated in Sullya syenite than Angadimogar, Sivamalai, Elagiri and Sundamalai. The Sullya and Angadimogar syenites show negative Eu anomalies, while the Sivamalai, Elagiri and Sundamalai syenites show positive Eu anomalies. Of all the five plutons north of CSZ, Elagiri syenites seems to be significantly least REE fractionated and less evolved than Sullya, Angadimogar, Sivamalai and Sundamalai syenites.

Mafic granulites, that host Sullya syenite, have a wide range of $\mathrm{SiO}_{2}$ (54-62 wt.\%; table 1) and variable $\mathrm{TiO}_{2}\left(0.8-2.1\right.$ wt.\%) and $\mathrm{Al}_{2} \mathrm{O}_{3}(9.9-16.8$ wt.\%). They have moderate concentrations of $\mathrm{MgO}$ (3.2-9.3 wt.\%), Ca (5-11.2 wt.\%) and $\mathrm{Na}(1.8-4.6$ wt.\%) (table 1). Rubidium contents of the studied granulites (avg. $4 \mathrm{ppm}$ ) are lower than average crustal rocks (84 ppm; Rudnick and Gao 2003). On an average, these granulites have $\mathrm{K}$-contents lower than 1 wt.\% with high K/Rb ratios (avg. 1971). Sr (avg. $343 \mathrm{ppm}$ ) contents are higher than the average crustal abundance (320 ppm). Nickel and cobalt content increases with $\mathrm{SiO}_{2}$ as that of $\mathrm{MgO}$.

Compared to the major oxide abundances in the studied host mafic granulites, the Sullya syenite are enriched in $\mathrm{Al}_{2} \mathrm{O}_{3}, \mathrm{~K}_{2} \mathrm{O}$ and $\mathrm{Na}_{2} \mathrm{O}$ and are depleted in $\mathrm{TiO}_{2}, \mathrm{Fe}_{2} \mathrm{O}_{3}, \mathrm{MgO}, \mathrm{CaO}$ and $\mathrm{P}_{2} \mathrm{O}_{5}$ (table 1). The abundance of large ion lithophile elements (LILE) and most high-field strength elements (HFSE) in the Sullya syenite are low compared with the host mafic-granulites. However, Sullya syenite are marked by higher abundances of $\mathrm{Nb}$ $(13-21 \mathrm{ppm})$ and $\operatorname{REE}(\Sigma \mathrm{REE}=152-706 \mathrm{ppm})$ than mafic granulites $(\mathrm{Nb}=8-19 \mathrm{ppm}$; $\Sigma \mathrm{REE}=97-395 \mathrm{ppm})$. Compared to Sullya syenite, the host mafic granulites show weak-to-moderate LREE enrichment and moderate $\mathrm{Eu} / \mathrm{Eu}^{*}$ anomalies $\left[(\mathrm{La} / \mathrm{Sm})_{\mathrm{N}}=1-2 ; \mathrm{Eu} / \mathrm{Eu}^{*}=0.1-0.2\right]$ along with relatively flat HREE patterns (figure 7a). Primitive mantle-normalized multielement patterns for the Sullya syenites (figure 6c) display deep troughs at Nb-Ta, Zr-Hf, Ti and Y. Similar depletion troughs are also observed in the host mafic-granulites (figure $7 \mathrm{~b}$ ).

\section{Discussion}

Based on the geochemical and isotopic systematics variability, four general models reflecting the diversity of geological settings have been proposed to explain the genesis of alkaline complexes. The first model involves mixing, in which the mantlederived, silica-undersaturated alkaline magmas mix with the magma derived from the lower crust (Dorais 1990) or the mixing of basic and silicic melts with subsequent differentiation of the hybrid liquids (Sheppard 1995). The second model invokes partial melting of a metasomatized mantle (Sutcliffe et al. 1990; Lynch et al. 1993). The third 
model involves the residual melts formed by differentiation of mantle derived alkali basalts (Parker 1983; Thorpe and Tindle 1992). The fourth model involves partial melting of the crustal rocks resulting from an influx of volatiles (Lubala et al. 1994) or in a closed system at pressures typical of the base of over-thickened crust (Huang and Wyllie 1981) with addition of alkalis.

More than 20 alkaline complexes have been reported in the southern granulite terrain (SGT) of Indian shield, all of them occurring in close proximity to or within the crustal-scale shear zones (figure 1; Ratnakar and Leelanandam 1989). These crustal scale shear zones (Moyar, Bhavani, Mercara, Palghat-Cauvery, Salem-Attur and Dharmapuri-Mettur) represent the boundaries between different crustal blocks (Coorg, Nilgiri, Salem, Biligiri Rangan Hills, Madras) in the northern part of the SGT.

Miyazaki et al. (2003) proposed that the syenite magmas of Elagiri alkaline complex in the Dharmapuri Shear Zone (DSZ) were generated from highly differentiated mantle-derived alkali basalts. These syenites show evolved $\mathrm{Sr}$ and $\mathrm{Nd}$ isotopic compositions, pronounced enrichment in LILE and large negative $\mathrm{Nb}$ anomalies, similar to those of the subduction-related alkaline rocks. However, in the absence of any evidence for subduction in these localities, Miyazaki et al. (2003) interpreted that the alkaline rocks were derived from subcontinental lithospheric mantle, which was previously enriched by slab-derived component (see Ratnakar 2007) in a rift-related geodynamic setting. In contrast, based on petrographic and geochemical characteristics, Mukhopadhyay et al. (2011) suggested liquid immiscibility of the alkali basaltic-magma source, derived from the continental lithospheric mantle (CSM), as the process responsible for the origin of Elagiri alkaline complex. According to these authors, liquid immiscibility gave rise to carbonatites and silicate rocks which are in close spatial association in Elagiri. Renjith et al. (2016a), based on lithological assemblages and geochemical evidence, proposed that the source magma of Sundamalai alkaline complex in the DSZ $(\sim 25 \mathrm{~km}$ north of Elagiri alkaline complex) was generated by partial melting of a metasomatized mafic lower-crustal source enriched in alkalis due to asthenospheric upwelling in a rift related geodynamic setting. Upadhyay et al. (2006) speculated that the ferrosyenites of Sivamalai alkaline complex in Palghat-Cauvery Shear Zone (PCSZ) are the products of crustal assimilation by an enriched and undersaturated nepheline syenite parent magma while the depleted nepheline syenites formed by fractional crystallization involving the removal of accessory phases. The geodynamic setting in which these plutons are intruded into the country rocks is not clear. Fractional crystallization of a heterogeneous magma that is generated by the interaction/ mixing of the asthenospheric mantle-derived melt with metasomatized continental mantle lithosphere-derived melt at variable proportions is suggested for the genesis of Angadimogar syenites and Peralimala ultrapotassic granites of Mercara Shear Zone (MSZ) and Moyar Shear Zone (MoSZ), respectively (Santosh et al. 2014). A complex model involving asthenospheric upwelling along an aborted rift and interaction of the magmas with lower crustal domains carrying accreted subduction-related components of various ages are proposed to explain the contrasting geochemical results (indicating rift and subduction characteristics) found in the Angadimogar syenites and Peralimala ultrapotassic granites (Santosh et al. 2014).

Some of the significant field and geochemical characteristics observed during this study in the syenites of Sullya are: (a) absence of bimodal rock suite association, (b) absence of alkaline basic rocks and ultramafic-mafic enclaves, (c) lack of igneous rocks of intermediate composition, (d) relative abundance of large-ion lithophile elements (LILE), and (e) lower concentrations of magnesium, nickel and cobalt. Petrographic characteristics of Sullya syenite suggest that there were two stages of crystallization. Based on the evolved and variable Hf-isotopic signatures coupled with their enriched mantle signatures in the sub-continental lithospheric mantle in the proximity of the nearby Angadimogar alkali pluton, Santosh et al. (2014) suggested interaction/mixing of asthenospheric mantle with metasomatised continental lithospheric mantle in variable proportions to generate the melt source of Angadimogar alkali pluton.

Two stages of crystallization are revealed in the petrographic studies of Sullya syenites. During the first stage, early formed accessory phases like zircon and apatite were enclosed as inclusions in the later crystallized plagioclase and K-feldspars. Subsequently, the second stage of crystallization is marked by the occurrence of aegirine, ribeckite, albite and minor amount of quartz that crystallized as clots and in the interstitial spaces between K-feldspar crystals. Weak alignment of the longer 

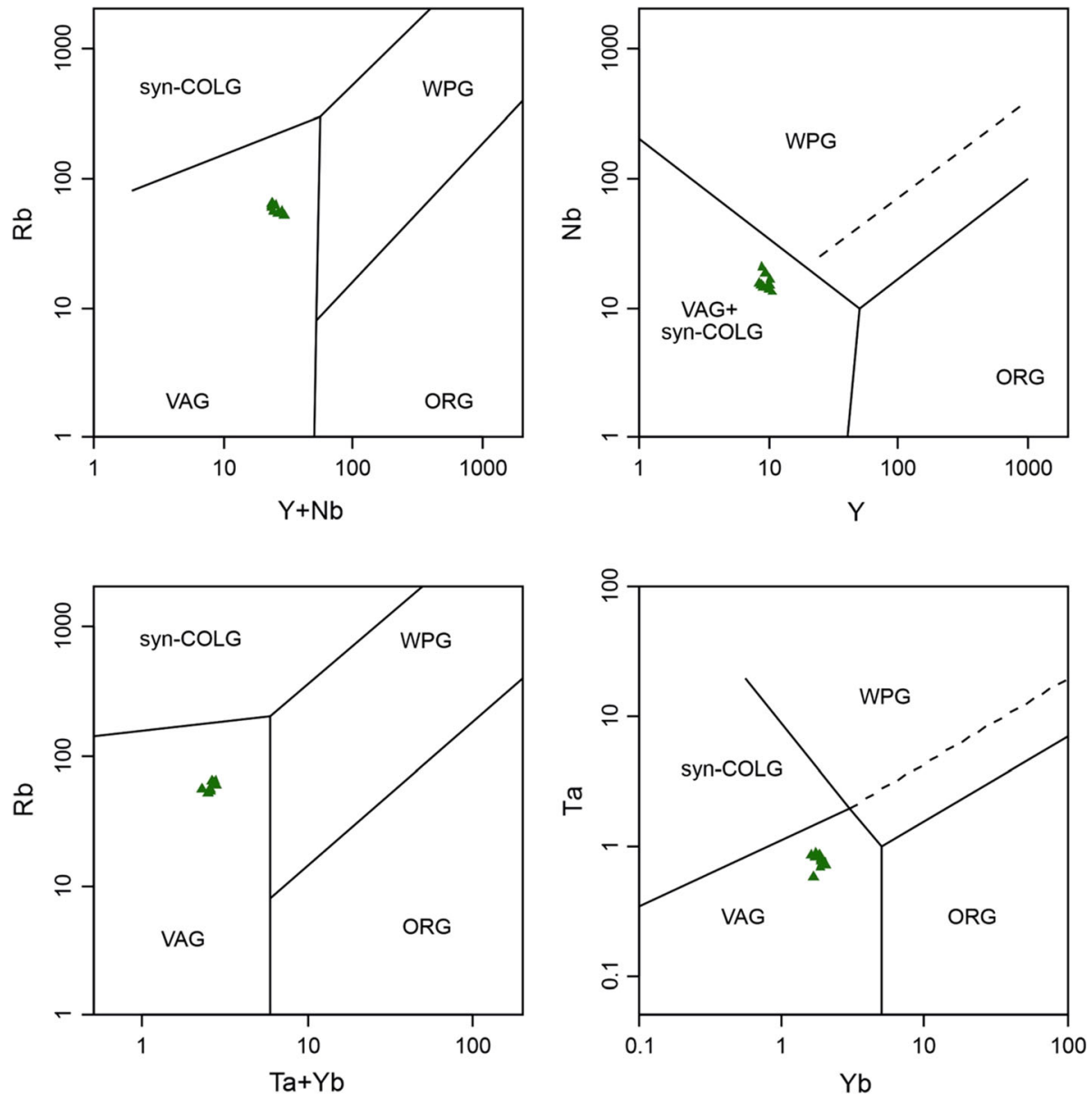

Figure 8. Tectonic discrimination diagrams of syenites (after Pearce et al. 1984).

axis of feldspar phenocrysts and mafic clots within the Sullya syenite suggests melt-supported deformation. Moreover, there is clear evidence of solid state ductile shearing that is conspicuous in both mafic clots and feldspars (figure 3). All these features suggest a heterogeneous magmatic source responsible for the origin of Sullya syenite and the magmatism was contemporaneous with shearing.

The first stage of crystallization in Sullya syenite is possible only with a silica undersaturated melt in order to account for the lack of quartz found in the first stage crystals ( $\mathrm{plg}+\mathrm{kfs} \pm \mathrm{zr} \pm \mathrm{ap})$. This silica undersaturated melt could have been derived from partial melting of metasomatized continental lithospheric mantle (Sorbadere et al. 2013; Santosh et al. 2014). The second stage mineral assemblages require sodic melt that has significant volatile content to account for the crystallization of sodicphases and ribeckite \pm arfvedsonite (Hibbard 1995). Partial melting of mafic rocks under elevated pressure generates sodic and magnesium rich melt (cf. Renjith et al. 2016a). The granulite facies rocks with 9 kbar metamorphic assemblages in and around the study area indicate the presence of thicker crust. Partial melting of such a thick crust could have possibly generated the melt that resulted in the formation of alkaline melt. The relatively high HFSE and REE in the Sullya syenite is indicative of a protolith enriched in these elements or a source that is heterogeneous. The studied syenites have a fractionation trend with the host mafic granulites in the major oxide variation diagrams (Supplementary figure S1). They also show similar depletion patterns of HFSE in primitive mantle normalized diagram (figure 6c) suggesting their genetic relationship with mafic granulites. Therefore, it is likely that partial melting of metasomatic mafic lower-crustal granulitic rocks at elevated pressure resulted in the alkaline melt. Interaction/mixing of the two melts at variable proportions could have resulted in the heterogenous melt that resulted in the formation of Sullya syenite. Mafic magmatic enclaves found in the nearby Angadimogar syenite pluton within MSZ 
also support a significant role for magma mixing in the origin of the melt that resulted in the Angadimogar alkaline pluton (Santosh et al. 2014).

\subsection{Emplacement history}

Alkaline magmatism has been reported from both riftand subduction-related tectonic regimes (Taylor et al. 1980; Pearce 1983; Druecker and Gay 1987; Fitton 1987; Mukhopadhyay et al. 2011; Santosh et al. 2014; Renjith et al. 2016a, b). The rift-related alkaline magmatism generally results in A-type peralkaline suite of rocks with hornblende, biotite, aegirine, fayalite, ribeckite and arfvedsonite as associated minerals. They are derived from partial melting of mantle and/ or lower anhydrous crust and indicate anorogenic affinity in tectonic classification diagrams (Pitcher 1983, 1993; Barbarin 1990). On the other hand, the subduction related alkaline magmatism generally results in metaluminous to peralkaline suite of rocks with predominantly hornblende and biotite as associated minerals (Pitcher 1983, 1993; Barbarin 1990). They are derived from partial melting of mantle derived mafic underplated material along with crustal contamination and indicate volcanic arc (island- or continental-arc) affinity in tectonic classification diagrams (Pitcher 1983, 1993; Barbarin 1990).

In this study, the syenites are associated with mylonitic gneisses and khondalites and granulites. Syenites show intrusive relation with host granulites and gneisses. The longer axis of the syenite pluton in Sullya is parallel to the shear plane of Mercara Shear Zone (MSZ) with medium to steep southerly dip (contact plane). The steep dipping perpendicular

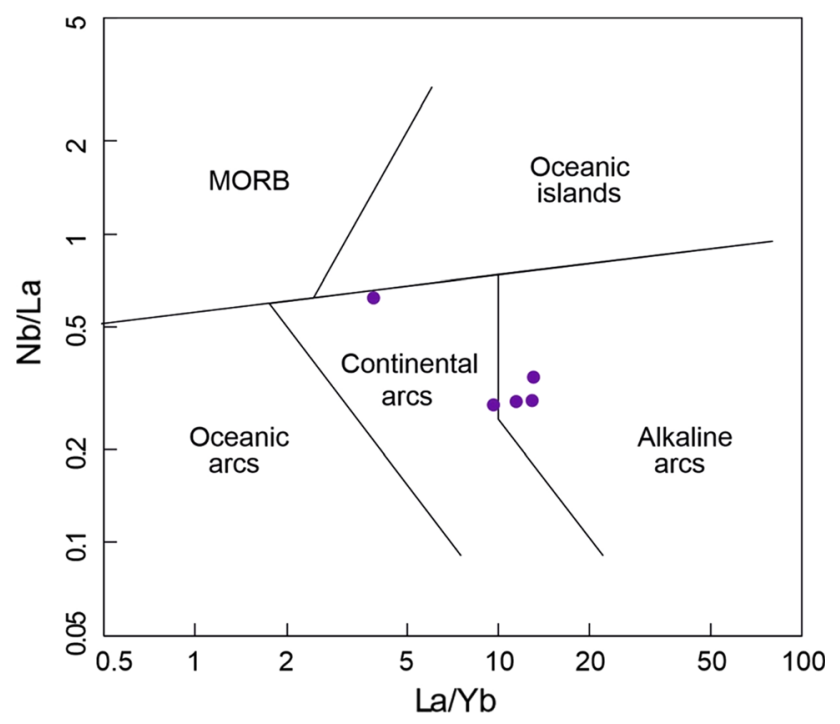

Figure 9. La/Yb vs. Nb/La plot of mafic-granulites (after Hollocher et al. 2012). pairs of joints are filled with fine-grained secondary basaltic material. The syenites are associated with alkaline and potassic granites (Santosh et al. 2014). The geochemical and mineralogical characteristics (with predominantly aegirine + ribeckite \pm arfvedsonite \pm hornblende \pm biotite as mafic phases) of the syenites indicate that they are hybrid metaluminous. Petrogenetically they appear to be derived from the mixing of the partial melts of metasomatized continental lithospheric mantle and mafic lower crustal granulitic rocks. All these features suggest that the Sullya syenite were emplaced in a rift related extensional tectonic regime.

However, when plotted on the tectonic discrimination diagrams involving $\mathrm{Rb}, \mathrm{Y}, \mathrm{Nb}, \mathrm{Ta}$ and $\mathrm{Yb}$, the Sullya syenite cluster in the field of volcanicarc-granite (and syn-collisonal granites) (figure 8). They also show pronounced negative $\mathrm{Nb}-\mathrm{Ta}$, $\mathrm{Zr}-\mathrm{Hf}$ and $\mathrm{Ti}$ anomalies suggesting an island arc setting. We interpret this contrast as a reflection of source heterogeneity in which the source, having the traces of arc magmatism, was emplaced in a rift setting. This is also corroborated by the field evidence and arc affinity of the mafic granulites (from which the syenite melt could have been derived) as indicated in $\mathrm{La} / \mathrm{Yb}-\mathrm{Nb} / \mathrm{La}$ diagram (figure 9) and by significant negative $\mathrm{Nb}-\mathrm{Ta}, \mathrm{Zr}-\mathrm{Hf}$ and $\mathrm{Ti}$ anomalies (figure $7 \mathrm{~b}$ ) of mafic granulites.

\section{Conclusions}

The isolated body of Sullya syenite shows an intrusive relationship with the host hornblende-biotite gneisses and mafic granulites. They lack macroscopic foliations and unlike, other plutons, Sullya syenite are not associated with carbonatites and ultrapotassic granites. K-feldspar and plagioclase dominates the felsic phases in Sullya syenite and there is negligible quartz. They show evidence of melt supported deformation but show no evidence of recrystallization. Geochemically, they mostly resemble Angadimogar syenites with similar major oxide and trace element concentrations. The petrogenetic studies of Sullya syenite have indicated that they were generated by the mixing of two different sources derived from the partial melting of metasomatized continental mantle lithosphere and lower crustal mafic granulites. This melt source could have probably been emplaced in a rift-related tectonic setting. The emplacement seems to be controlled by shears. 


\section{Acknowledgements}

Dr H M Ramachandra is thanked for his suggestions during the course of manuscript preparation. He is also thanked for his continuous support and guidance. Dr Ishwar-Kumar and Dr Indra Sen are thanked for their help in obtaining chemical analyses. CKB thanks the Head, Department of Geology, Central University of Kerala for providing infrastructural facilities to carry out the present study.

\section{Appendix: Analytical methods}

Major oxides were analyzed by X-ray fluorescence (XRF) technique at National Centre for Earth Science Studies (NCESS), Trivandrum, India. Pressed pellets were used respectively for major element analysis. The pellets were prepared by sprinkling finely powdered sample over boric acid binder filled in aluminium cups and pressing in a 40-ton hydraulic press for $30 \mathrm{~s}$. Analyses were performed on a Bruker S4 Pioneer wavelength dispersive (WD) XRF instrument. The detection limit of major element was $\sim 0.01 \%$ and analytical precision is always better than $1 \%$. Precision for trace elements is estimated to be better than $5 \%$ on the basis of repeated analysis of reference rock standards (Ravindra Kumar and Sreejith 2016; Sorcar et al. 2019). The precision and accuracy of calibration curves and data reliability is available at http://cess.res.in/groups/crustal-proces ses-crpgroup/laborataries/xrf-lab-2.

Trace element concentration analyses were performed at Department of Earth Sciences in Indian Institute of Technology Kanpur. Approximately $0.25 \mathrm{~g}$ of sampler powder was initially digested in pre-cleaned teflon beakers at $130 \pm 5^{\circ} \mathrm{C}$ using a $5 \mathrm{~mL}$ mixture of concentrated HF (2 parts), concentrated $\mathrm{HCl}$ (1 part) and concentrated $\mathrm{HNO}_{3}(1$ part) for $48 \mathrm{hrs}$. The acid was then slowly evaporated at $80 \pm 5^{\circ} \mathrm{C}$, and again the samples were redissolved in $4 \mathrm{~mL}$ of Aqua Regia acid $(3 \mathrm{~mL}$ of concentrated $\mathrm{HNO}_{3}+1 \mathrm{~mL}$ of concentrated $\mathrm{HCl}$ ). Aqua Regia was fluxed for $24 \mathrm{hrs}$. Further, the samples were dried and re-dissolved in $5 \% \mathrm{HNO}_{3}$. The acid digestion steps were only repeated when digestion was incomplete. Trace element concentrations were determined at $\sim 200$ ppm total dissolved solid solutions. Three procedural blanks, reference material SBC-1 (shale) and AGV-2 (andesite) rock standard from US Geological Survey (USGS) were also digested following the same procedures. The blanks were analyzed to quantify the total procedural blank, whereas AGV-2 was analyzed as an unknown to assess the data quality. SBC-1 was diluted to seven appropriate concentrations to construct the calibration curve, and trace element concentrations were determined based on the SBC-1 calibration curve. Since rock-matrix matched reference materials were unavailable, all the samples and standards were spiked by $\sim 5 \mathrm{ppb}$ In solution and In was used as an internal standard. The instrument was run both in standard and $\mathrm{He}$ kinetic energy discrimination mode to optimize the separation of measured isotopes from interfering polyatomic interferences. The final concentrations were blank - corrected using the average procedural blank concentrations and matrix effect was corrected by In normalization. Average blank corrections were less than $10 \%$ for most of the elements. The measured trace element concentration of AGV2 agrees well with the USGS certified values.

\section{References}

Barbarin B 1990 Granitoids: Main petrogenetic classification in relation to origin and tectonic setting; Geol. J. 25 $227-238$.

Bonin B 2004 Do coeval mafic and felsic magmas in postcollisional to within-plate regimes necessarily imply two contrasting, mantle and crustal, sources? A review; Lithos 78 1-24.

Bose M K 1971 Petrology of the alkalic suite of Sivamalai Coimbatore, Tamil Nadu; J. Geol. Soc. India 12(3) 241-261.

Chetty T R K, Bhaskar Rao Y J and Narayana B L 2003 A structural cross section along Krishnagiri-Palani corridor, Southern Granulite Terrain of India; In: Tectonics of Southern Granulite Terrain-Kuppam-Palani Transect (ed.) Ramakrishnan M, pp. 255-278.

Chetty T R K, Mohanty D P and Yellappa T 2012 Mapping of shear zones in the Western Ghats, southwestern part of Dharwar Craton; J. Geol. Soc. India 79 151-154.

Collins A S, Clark C and Plavsa D 2014 Peninsular India in Gondwana: The tectonothermal evolution of the Southern Granulite Terrain and its Gondwanan counterparts; Gondwana Res. 25 190-203.

Dorais M J 1990 Compositional variations in pyroxenes and amphiboles of the Belknap Mountain complex, New Hampshire: Evidence for the origin of silica-saturated alkaline rocks; Am. Mineral. 75 1092-1105.

Druecker M D and Gay Jr S P 1987 Mafic dyke swarms associated with Mesozoic rifting in Eastern Paraguay, south America; In: Mafic Dyke Swarms (eds) Halls H C and Fahrig W F, Geol. Assoc. Canada 34 187-193.

Fitton J G 1987 The Cameroon Line, West Africa: A comparison between oceanic and continental alkaline volcanism; In: Alkaline Igneous Rocks (eds) Fitton J G and Upton B G; Geol. Soc. Spec. Publ. 30 273-291. 
Fitton J G and Upton B G 1987 Alkaline Igneous Rocks; Geol. Soc. Spec. Publ. 30568.

Ghosh J G, de Wit M J and Zartman R E 2004 Age and tectonic evolution of Neoproterozoic ductile shear zones in the Southern Granulite Terrain of India, with implications for Gondwana studies; Tectonics 23 1-38.

Hibbard M J 1995 Mixed magma rocks; In: Petrography to Petrogenesis, Prentice-Hall, Englewood Cliffs, NJ, pp. 242-260.

Hollocher K, Robinson P, Walsh E and Roberts D 2012 Geochemistry of amphibolite-facies volcanics and gabbros of the Storen Nappe in extensions west and southwest of Trondheim, western gneiss region, Norway: A key to correlations and paleotectonic settings; Am. J. Sci. 312(4) 357-416.

Huang W L and Wyllie P J 1981 Phase relationships of S-type granite with $\mathrm{H}_{2} \mathrm{O}$ to $35 \mathrm{kbar}$ : Muscovite granite from Harney Peak, South Dakota; J. Geophys. Res. Solid Earth 86 10,515-10,529.

Le Bas M J J, Maitre R W L, Streckeisen A and Zanettin B 1986 A chemical classification of volcanic rocks based on the total alkali-silica diagram; J. Petrol. 27 745-750.

Lu R, Liang T, Bai F J and Lu X X 2013 LA-ICP-MS U-Pb Zircon Age and Hf Isotope composition of Mogou Syenite, western Henan Province; Geol. Rev. 59 355-368

Lubala R T, Frick C, Rogers J H and Walraven F 1994 Petrogenesis of syenites and granites of the Schiel Alkaline Complex, Northern Transvaal, South Africa; J. Geol. 102 307-316.

Lynch D J, Musselman T E, Gutmann J T and Patchett P J 1993 Isotopic evidence for the origin of Cenozoic volcanic rocks in the Pinacate volcanic field, northwestern Mexico; Lithos 29 295-302.

Menzies M 1987 Alkaline rocks and their inclusions: a window on the Earth's interior; In: Alkaline Igneous Rocks (eds) Fitton J G and Upton B G, Geol. Soc. Spec. Publ. 30 $115-127$.

Miyazaki T, Kagami H, Ram Mohan V, Shuto K and Morikiyo T 2003 Enriched subcontinental lithospheric mantle in the northern part of the South Indian Granulite Terrain: Evidence from Yelagiri and Sevattur Syenite Plutons, Tamil Nadu, South India; Gondwana Res. 6 585-594.

Miyazaki T, Kagami H, Shuto K, Morikiyo T, Ram Mohan V and Rajasekaran K C 2000 Rb-Sr Geochronology, Nd-Sr Isotopes and whole rock geochemistry of Yelagiri and Sevattur Syenites, Tamil Nadu, South India; Gondwana Res. 3 39-53.

Mukhopadhyay S, Ray J, Balaram V, Keshav Krishna A, Ghosh B and Mukhopadhyay S 2011 Geochemistry and petrogenesis of syenites and associated rocks of the Elagiri complex, Southern Granulite Terrane, India; J. Asian Earth Sci. 42 1256-1270.

Müller D Rock N M S and Groves D I 1992 Geochemical discrimination between shoshonitic and potassic volcanic rocks in different tectonic settings: A pilot study; Mineral. Petrol. 46 259-289.

Parker D F 1983 Origin of the trachyte-quartz trachyte-peralkalic rhyolite suite of the Oligocene Paisano volcano, Trans-Pecos Texas; Geol. Soc. Am. Bull. 94 614-629.

Pearce J A 1983 The role of subcontinental lithosphere in magma genesis at active continental margins; In: Continental basalt and mantle xenoliths (eds) Hawkesworth C J and Norry M J, Nantwich, UK: Shiva Publishing, Ltd., $230-249$.

Pearce J A, Harris N B W and Tindle A G 1984 Trace element discrimination diagrams for the tectonic interpretation of granitic rocks; J. Petrol. 25 956-983, https://doi.org/10. 1016/j.gsf.2019.05.013.

Peccerillo A and Taylor S R 1976 Geochemistry of Eocene calc-alkaline volcanic rocks from the Kastamonu area, northern Turkey; Contrib. Mineral. Petrol. 58(1) 63-81.

Pitcher W S 1983 Granite type and tectonic environment; In: Mountain Buiding Processes (ed.) Hsu K, Academic Press, London, pp. 19-40.

Pitcher W S 1993 The Nature and Origin of Granite; London, Blackie.

Rao B B 1982 Petrology of the alkaline rocks around Sivamalai, Coimbatore district, Tamilnadu, India; Geologische Rundschau 71 263-279.

Ratnakar J 2007 Lithosphere control of the Proterozoic alkaline magmatism: the miaskitic nepheline syenites of southern India; In: The Evolution of the Indian Continental Crust and Upper mantle, Gondwana Res. 10 109-121.

Ratnakar J and Leelanandam C 1989 Petrology of the alkaline plutons from the eastern peninsular India; In: Alkaline Rocks (eds) Leelanandam C, Geol. Soc. India Memoir 15 $145-176$.

Ravindra B M and Janardhan A S 1981 Preliminary report on aegerine augite bearing syenite near Sullia Town, Dakshina Kannada District, Karnataka; J. Geol. Soc. India 22 399-402.

Ravindra Kumar G R and Sreejith C 2016 Petrology and geochemistry of charnockites (felsic ortho-granulites) from the Kerala Khondalite Belt, Southern India: Evidence for intra-crustal melting, magmatic differentiation and episodic crustal growth; Lithos 262 334-354.

Rekha S, Bhattacharya A and Chatterjee N 2014 Tectonic restoration of the Precambrian crystalline rocks along the west coast of India: Correlation with eastern Madagascar in East Gondwana; Precamb. Res. 252 191-208.

Renjith M L, Santosh M, Li T, Satyanarayanan M, Korakoppa M M, Tsunogae T, Rao D V S, Keshav Krishna A and Charan S N 2016a Zircon U-Pb age, Lu-Hf isotope, mineral chemistry and geochemistry of Sundamalai peralkaline pluton from the Salem Block, southern India: Implications for Cryogenian adakite-like magmatism in an aborted-rift; J. Asian Earth Sci. 115 321-344.

Renjith M L, Santosh M, Satyanarayanan M, Subba Rao D V and Li T 2016b Multiple rifting and alkaline magmatism in southern India during Paleoproterozoic and Neoproterozoic; Tectonophys. $680233-253$.

Rudnick R L and Gao S 2003 Composition of the continental crust; In: Treatise on Geochemistry, The Crust (ed.) Rudnick R L, Elsevier 3 1-64.

Santosh M, Maruyama S and Sato K 2009 Anatomy of a Cambrian suture in Gondwana: Pacific-type orogeny in southern India? Gondwana Res. 16 321-341.

Santosh M, Yang Q-Y, Ram Mohan M, Tsunogae T, Shaji E and Satyanarayanan M 2014 Cryogenian alkaline magmatism in the Southern Granulite Terrane, India: Petrology, geochemistry, zircon $\mathrm{U}-\mathrm{Pb}$ ages and $\mathrm{Lu}-\mathrm{Hf}$ isotopes; Lithos 208 430-445.

Schleicher H, Kramm U, Pernicka E, Schidlowski M, Schmidt F, Subramanian V, Todt W and Viladker S G 
1998 Enriched subcontinental upper mantle beneath southern India: Evidence from $\mathrm{Pb}, \mathrm{Nd}, \mathrm{Sr}$, and $\mathrm{C}-\mathrm{O}$ isotopic studies on Tamil Nadu Carbonatites; J. Petrol. 39 1765-1785.

Schleicher H, Todt W, Viladkar S G and Schmidt F 1997 Pb/ $\mathrm{Pb}$ age determinations on the Newania and Sevattur carbonatites of India: Evidence for multi-stage histories; Chem. Geol. 140 261-273.

Sheppard S 1995 Hybridization of shoshonitic lamprophyre and calc-alkaline granite magma in the early Proterozoic Mt Bundey igneous suite, Northern Territory; Aust. J. Earth Sci. 42 173-185.

Sorbadere F, Medard E, Laporte D and Schiano P 2013 Experimental melting of hydrous peridotite-pyroxenite mixed sources: Constraints on the genesis of silica-undersaturated magmas beneath volcanic arcs; Earth Planet. Sci. Lett. 384 42-56.

Sorcar N, Joshi K B, Oliviera E P, Tomson J K and Nandakumar V 2019 Characterization of partial melting events in garnet-cordierite gneiss from the Kerala Khondalite Belt, India; Geosci. Front., https://doi.org/10.1016/ j.gsf.2019.05.013.

Subramaniam A P 1948 A petrographic study of the alkaline rocks at Sivamalai; Proc. Indian Acad. Sci. 30 69-94.
Sun S-S and McDonough W F 1989 Chemical and isotopic systematics of oceanic basalts: Implications for mantle composition and processes; In: Magmatism in oceanic basins (eds) Saunders A D and Norry M J, Geol. Soc. London, Spec. Publ., pp. 313-345.

Sutcliffe R H, Smith A R, Doherty W and Barnett R L 1990 Mantle derivation of Archean amphibole-bearing granitoid and associated mafic rocks: Evidence from the southern Superior Province, Canada; Contrib. Mineral. Petrol. 105 255-274.

Tchameni R Mezger K Nsifa N E and Pouclet A 2001 Crustal origin of Early Proterozoic syenites in the Congo Craton (Ntem Complex), South Cameroon; Lithos 57 23-42.

Taylor P N, Moorbath S, Goodwin R and Petrykowski A C 1980 Crustal contamination as an indicator of the extent of early Archaean continental crust: $\mathrm{Pb}$ isotopic evidence from the late Archaean gneisses of West Greenland; Geochim. Cosmochim. Acta 44 1437-1453.

Thorpe R S and Tindle A G 1992 Petrology and petrogenesis of a tertiary bimodal dolerite-peralkaline/subalkaline trachyte/rhyolite dyke association from Lundy, Bristol Channel, UK; Geol. J. 27 101-117.

Upadhyay D, Jahn-Awe S, Pin C, Paquette J L and Braun I 2006 Neoproterozoic alkaline magmatism at Sivamalai, southern India; Gondwana Res. 10 156-166.

Corresponding editor: N V CHALAPathi RaO 